\title{
Environmental Worry of River State Residents in the Niger Delta Region, Nigeria
}

\author{
Olusola I. Akinbobola ${ }^{1 *}$, Bernard E. Njor ${ }^{2}$ \\ ${ }^{1}$ Department of Behavioural Studies, Redeemer's University, Redemption City, Nigeria \\ ${ }^{2}$ Academic Planning \& Quality Assurance, Redeemer’s University, \\ Redemption City, Nigeria \\ Email: ${ }^{\text {solaakinbobola@yahoo.co.uk }}$
}

Received August 20 ${ }^{\text {th }}$, 2013; revised September 21 ${ }^{\text {st }}$ 2013; accepted October $17^{\text {th }}, 2013$

\begin{abstract}
Copyright (c) 2014 Olusola I. Akinbobola, Bernard E. Njor. This is an open access article distributed under the Creative Commons Attribution License, which permits unrestricted use, distribution, and reproduction in any medium, provided the original work is properly cited. In accordance of the Creative Commons Attribution License all Copyrights $\odot 2014$ are reserved for SCIRP and the owner of the intellectual property Olusola I. Akinbobola, Bernard. E. Njor. All Copyright (C 2014 are guarded by law and by SCIRP as a guardian.
\end{abstract}

Human-made cataclysmic events from over 50 years of oil production, gas explosions, and oil spillages soak the Niger Delta pose psychological challenges to the people in the environment. Thus this study examined environmental worry of Rivers State residents of Niger Delta, Nigeria. Data collected were analysed using independent t-test and one-way ANOVA. The findings of the FGD revealed that there is an awareness of loss of land, loss of control of technical networks in oil production and experience of environmental degradation. Additionally, the survey results showed a significant difference on environmental worry based on sex and age. However, nativity, employment status and educational status did not significantly differentiate between groups on environmental worry. The implication of the results of the study is discussed in line with relevance of residents' expectations, prospects and choice of enduring lifestyle, living and survival.

Keywords: Environmental Worry; Environmental Degradation; Niger Delta

\section{Introduction}

Nearly everyone worries at some time, when they face something new or unknown. Worry is an apprehensive way of thinking about oneself, the world and future events. It usually involves thoughts about what bad things might happen in the future and whether the person will be able to cope with them. Worrying is usually triggered by a reminder in the environment that is related to the area of danger. Low worry usually interferes a little with daily life, because the person is usually able to stop it. However the frequency of worry and the extent of apprehension it causes are different for everyone.

Human use of technology in oil production occasionally leads to loss of control over the technical network leading to incidence of cataclysmic events in the environment. Apprehension for humans, animals and plants' survival and safety may cause environmental worry. Environmental worry is an emotional reaction and thoughts to unavoidable and perpetual cataclysmic events which may degrade environment as experienced in Niger Delta region of Nigeria.

The Nigeria's Niger Delta region contains the world's third largest wetland (Bruce \& Young, 1998), however oil exploration and gas production led to pollution, depletion and disappearance of wetlands (World Bank, 2007). The Niger Delta is overwhelmed with environmental degradation, lack of employment, poor educational facilities and lack of social amenities (Obadan \& Chokor, 2013). Wealth from the resources of *Corresponding author. the Niger Delta is the mainstay and bedrock of Nigeria's economy yet the region is in deplorable state.

There is incidence of oil production, experiences of gas flaring, cataclysmic events of 6817 oil spillages in the entire Niger Delta (UNDP, 2006). Specifically in River State, Eleme devastatingly has two out of four petroleum refineries in Nigeria (Udogu, 2005); Ogoniland experienced 2976 life threatening oil spillages (Crayford, 1996) and Bodo had occurrences of incessant gas explosion (Pegg \& Zabbey, 2013). Ever since the late 1950 's, the Niger Delta has been recognised as a region requiring special development attention.

Furthermore, UNDP (2006) highlighted neglect of human development in aspects of physical and environmental development of the Niger Delta, suggesting a low rating of human development of Niger Delta when compared to similar oil producing regions in the world. Distributive justice (Adams, 1965; Deustch, 1975; Forsyth, 2006) of perceived fairness in decision-making based on equity, needs and/or equality is not adhered to concerning Niger Delta development. Human confidence is often shaken over controllability of human-made technological network mishap in the oil rigs. Loss of control, lack of development and equitable justice may stimulate apprehension of the residents and eventual environmental worry.

\section{Literature Review}

Stokols (1978), Rodin and Baum (1978) proposed the behaviour constraint model. The behaviour constraint model is 
based on adaptation level theory developed by Wohlwill (1974) which expounded that humans usually prefer an optimal level of stimulation. According to behaviour constraint model (Stokols, 1978) a potential consequence of optimal level of stimulation is loss of perceived control over an event, danger or impaired environment. The term constraint is a cognitive interpretation of the situation suggesting that the environmental event is beyond a person's control thereby limiting the person's behaviour.

The behaviour constraint model posited three basic steps which are perceived loss of control, psychological reactance and learned helplessness. Initially, the person either loses some degree of control or perceives that he/she has lost control. Later, the person experiences discomfort which is a negative effect and thereby reasserts control over the situation termed psychological reactance (Brehm \& Brehm, 1981). When psychological reactance is unsuccessful, the ultimate consequence after several trials is learned helplessness (Garber \& Seligman, 1981).

Learned helplessness is when one repeatedly experiences a lack of control in altering bad life events. When an unpleasant situation is perceived to be inescapable, humans develop the belief that they are helpless to alter their circumstances by means of any voluntary behaviour. Due to the expectation that one's behaviour has no effect on outcome; the person simply gives up trying to change the outcome (Seligman \& Maier, 1967). Learned helplessness is less severe than death, it often leads to death (Seligman, 1992).

In a study conducted by (Hokka et al., 1999), air pollution, water pollution and survival of plant and animal species were discovered to be threats in some cities such as Helsinki, Moscow and Tallinn while the effects of pollution on individuals' health worried Estonian teenagers most. (Shusterman et al. 1991) found in California that adult residents living near hazardous waste sites reported environmental worry from frequency of perceiving petrochemical odours in the environment.

Adeola (2007) in a study in the USA pointed out that nativeborn subject score significantly lower on perception toward technological and environmental risk from disaster relative to foreign born subjects. Those who lived through the environmental disaster are aware of the risks more than those who have not. (Grattan et al., 2011) found subsequent to oil spillage among persons living in fishing communities along the Florida and adjacent Alabama coast a profound impact on their psychological adjustment and adaptation. There was also no significant difference between demographic groups on environmental worry.

Other researches were reported on demographic groups and environmental worry. Drottz-Sjoberg \& Sjoberg (1990) after Chernobyl disaster, a nuclear plant accident found that there was relationship between sex and worry, female reported much more worry than male did. There is only a very small difference between male and female respondents in Sweden (Sjoberg, 1998) on worry. In Tallinn, Hokka et al. (1999) indicated that sex differences in environmental worry were small.

Age co-varied with worry (Drottz-Sjoberg \& Sjoberg, 1990) and there is a tendency for worry to increase with age. For (Hokka et al., 1999) in Tallinn, age differences in environmental worry were small. Herr et al. (2000) found that age did not show a significant influence on worry. Another demographic variable which is level of education had influence on worry (Drottz-Sjoberg, 1990). Some researchers (Sjoberg \&
Drottz-Sjoberg, 1987; Sjoberg \& Drottz-Sjoberg, 1993) found that lower educational level is tied to higher environmental worry. Herr et al. (2000) also revealed that lower school education was associated with higher scores in environmental worry.

Unemployment culminates a negative impact on the individual socio-emotional need because work is an important part of daily life of most people Babalola (2010). Grattan et al. reported that participants with oil spill-related income loss and those with loss of job opportunities due to oil spill were less resilient and were more likely to use behavioural disengagement as a coping strategy. Eisenberger, Armeli, Fasolo, \& Lynch found that length of unemployment has influence on the socio-emotional resources of individuals. Unemployment may produce feelings of frustration, loneliness, anger and emasculation. Employment status may influence environmental worry.

Researchers (Akinbobola, 2012; Ehigie \& Ideozu, 1999; Ehigie, 2005; Nwoke, 2011) carried out previous research on psychological impact of oil spill in Niger Delta. The objective of the present study is to examine the influence of environmental worry among different demographic groups; and the knowledge of environmental degradation among residents of the oil producing area of Port-Harcourt, River State in the Niger Delta of Nigeria.

Based on the literature review the following hypotheses were stated:

1) Male participants will exhibit significantly higher environmental worry than female participants;

2) Native-born participants will exhibit significantly higher environmental worry than non-native participants;

3) Older participants will exhibit significantly higher environmental worry than younger participants;

4) Unemployed participants will exhibit significantly higher environmental worry than employed participants;

5) There will be significant difference of participants with no formal education, secondary education and tertiary education on environmental worry.

\section{Study I}

\section{Method}

\section{Research Design}

Study I employed a participatory design using Focus Group Discussion (FGD).

\section{Study Setting}

The FGD took place in Aleto, Eleme local government area; very close to Port-Harcourt.

\section{Participants}

10 males participated in the FGD in Aleto. All the discussants are residents of Eleme Local Government Area, very near Port-Harcourt. The members were made up of native-born residents and non-native residents.

\section{Qualitative Measure}

Both quantitative and qualitative methods of data collection were adopted in this study to strengthen the research design (Nwoke, 2011). The introspective nature of the study requires evaluation of residents' experience in the Niger Delta region of Nigeria, the research was able to analyse information from the FGD as qualitative measure. 
1) Focus Group Discussion

A focus group discussion was held. The FGD allowed for a large amount of interaction, in a limited amount of time to get diversified opinion and contribution of the discussants to the betterment of their environmental situation. A list of issues was highlighted to serve as guide for data gathering.

The purpose of the FGD was to:

a) Identify participants' level of awareness of loss of controllability of technology network and loss of land.

b) Elicit knowledge of environmental degradation and threat to life.

c) Examine attitudes and practices that constitute hindrance to avert technological mishap.

d) Identify level of willingness of social responsibility of companies and government intervention.

\section{Procedure}

The Focus Group Discussion (FGD) was conducted among 10 residents of Eleme local government area, Rivers State in the Niger Delta.

\section{Result}

Result of Focus Group Discussion

The FGD revealed on loss of land and loss of technological controllability that the companies took over half of the land. According to the participants, there are about 250 companies in Eleme Local Government Area. Their land disappeared to the companies without payment because of land use decree initiated by the Federal Government that all land belongs to the government.

On impact of environmental degradation, the participants complained about acid rainfall caused by gas flaring from companies and death of residents as a result of inhaling ammonia gas. According to the participants, Okwuri River is polluted because the companies still channel their waste through pipes to the river. Oil spillage in Ogale River caused the stream to dry up since 1989-1990. Therefore, instead of pure water they get "chemical", that is poisoned water from bore hole.

There is lack of food supply, the people are hungry and idle, and the participants affirmed that "a hungry man is an angry man”. Extinction of plants and animals led to importation of food such as cattle from outside their state. The cattle fed on polluted water and poisoned plants and the cattle may eventually die. If the meat of infected cattle is eaten by the people, such people will likely die of terminal disease. It is like they are going through the same cycle of problem, as asserted by the participants.

To worsen the situation, the participants said that government hospitals were moribund. The highest age of people is 45 - 54 years; child mortality rate is also high. Furthermore, the residents were neither aware of scholarships nor were they recipients of scholarships, the community leaders usurp such scholarship openings and opportunities for their relatives. There are no public facilities, no infrastructure and no development. There is housing problem, roads are in deplorable state. Employment is not given to indigenes. The companies source about $90 \%$ of their employees from outside this environment. Youth restiveness is high; militancy and kidnapping abounds. These vices of the youth, participants insisted filters from unemployment. The old people look on to what the future holds.

The participants on issues of attitudes and practices that con- stitute hindrance to prevent technological mishap reiterated that their leaders are the source of hindrance to the way forward in the community. The problem is not affecting community leaders but the common man. Some participants also mentioned poor representation from leaders which goes a long way in proffering solution to their problems. Cartels, that is, a few persons who collaborated with the companies, pounced on them, arrested them and use some of them as scapegoats. Therefore, they are forced to calm down.

On issues identifying level of willingness of social responsibility by companies and government intervention, the participants lamented that the companies drafted policies and published in national daily newspapers what they do not practice. Companies are residing here yet there is no employment for the people. The companies have 24 hours power supply, excessive turbines to generate power; but the host communities around them do not have power, that is manipulation.

"The way forward is a cry for help", they said. If you gather people they will bear their mind. The participants said that the people want to be heard, that their problems are enormous and too numerous; they agreed that they are all stakeholders.

\section{Discussion}

\section{Discussion of Findings for FGD}

Findings from FGD on the issue of participants level of awareness about loss of land and loss of controllability of technical network revealed loss of about half of their land to oil exploration. There is an awareness of man-made environmental problem, and interference with perfect endowment of nature. This finding supported (Stokols, 1978) behaviour constraint theory that there is loss of perceived control over the impaired environment by persons. This FGD finding also supported (World Bank, 2007) report that oil exploration led to disappearance of wetland. The participants made some comments.

"Industrialisation started in early 1960's, our occupation is farming, the land was better and yield was good. Now the land yields nothing, there is no more subsistence farmer, no more peasant farmer; we import food from other states".

The question on the knowledge of environmental degradation elicited response from the participants that degradation is a global issue and that all living things are affected. There is occurrence of climate change as evident in acid rain. This FGD finding supported (Obadan \& Chokor, 2013) that the Niger Delta is overwhelmed with environmental degradation, lack of employment, poor educational facilities, lack of social amenities. Participants' affirmation that they are all stakeholders corroborated (Grattan et al., 2011) finding that there was no significant difference among demographic groups on environmental worry. Participants captured their fears and knowledge of the situation.

"There is climate change since the inception of these companies".

"The colour of sun is bluish, air is dusty, sun is not as bright as it used to be. Incidentally when rain falls, the colour of rain water is muddy".

"Ironically Eleme is hobnob of economic activities, we are sitting inside dollar minting machine yet we are poor. Our land has been degraded. Some of us are farmers or fishermen but our means of livelihood is hampered. Nothing to show from government to ameliorate or cushion this suffering".

The question asked in the FGD on attitudes and practices that 
constitute hindrance to avert technological mishap highlighted poor representation by their community leaders when they complain; and arrest by soldiers when they protest. This FGD finding supported (UNDP, 2006) report on the neglect of the people of Niger Delta. The participants' responses are captured.

"South Africa apartheid is $100 \%$ better than what we are seeing in Eleme. We feel dejected, depersonalize; but you cannot commit suicide, no case of suicide. We go out on nonviolent demonstration”.

The question on the level of social responsibility by companies and government intervention revealed that FGD participants identified a cycle of problem. The cycle of problem was initiated by companies' activities emanating from loss of traditional job opportunities, lack of food, coupled with no education, no health care, to lack of offer of employment even by the companies that degraded the environment. The cycle is inclusive of marginalisation by government in terms of lack of social amenities and infrastructure. This finding supported (Akinbobola \& Njor, 2013) that perceived marginalisation influenced environmental worry among residents of the Niger Delta. The companies do not give back to the community especially the masses in the community, this finding collaborated (UNDP, 2006) low rating of human development in the Niger Delta and lack of distributive justice (Adams, 1965; Deustch, 1975; Forsyth, 2006). The participants complained.

"Those who are milking us have refused to adhere to the policy that will enable us to plant, produce and benefit from nature".

Who then is responsible for the human development of Niger Delta; government, companies or community leaders? The people in the Niger Delta, the economic backbone of Nigeria should not be endangered to psychologically worry over oil exploration in their environment which they perceive as oil exploitation. The residents identified an equitable treatment of both human and physical development. Therefore the FGD participants reported that because the residents were ignored, they become agitated, angry and led protest. Nigeria cannot afford restiveness and militancy in Niger Delta any longer. The situation in Niger Delta should not be allowed to degenerate to people resorting to suicide.

\section{Study II}

\section{Method}

Research Design

Study II employed a survey method.

\section{Study Setting}

The survey was conducted in the oil producing areas of PortHarcourt. Eleme and Port-Harcourt are in Rivers State, Niger Delta area, Nigeria.

\section{Participants}

Participants for the survey were 100 residents of Eleme and Port-Harcourt consisting of 67 males and 33 females aged 16 years to 69 years with mean age of 41.2 and standard deviation of 5.1. There were 81 younger and 19 older participants. Participants who are natives of River State are called native-born while those who are not natives of River State are called non-natives. Native-born were $88 \%$ and non-natives were $12 \%$, Employed participants were $30 \%$ and the unemployed were
$70 \%$. $9 \%$ of the participants had no formal education, $37 \%$ had primary/secondary education and $54 \%$ had tertiary education.

\section{Quantitative Measure}

The survey data was utilized as quantitative measure to check the consistency of the findings of the qualitative measure of the FGD and to make recommendation for further investigation.

1) Survey

In the survey, questionnaire was used to measure the factors in the study.

\section{2) Demographic Data}

Demographic factors such as sex, nativity, age, educational status and employment status were measured in Section A.

3) Environmental Worry Scale

The environmental worry scale in section B is a 17 item scale developed by (Bowler \& Schwarzer, 1991) and validated in 3 samples. The scale measures emotional distress from cataclysmic events. The scale is scored along a 4 point dimension ranging from "Not at all True" as (1) to "True" as (4). The present study reported Cronbach alpha of 0.69 .

\section{Procedure}

The participants in the survey were 100 adult residents from 16 to 69 years randomly selected from oil producing area of Port-Harcourt, River State in the Niger Delta of Nigeria. The questionnaires were given to the participants and collected back from them within 4 weeks. The subjects' confidentiality was assured and participation was voluntary.

\section{Result}

Demographic Characteristics of the Participants

Participants for the survey were 100 residents consisting of 67 males and 33 females aged 16 to 69 years with mean age of 41.21 and standard deviation of 5.11 from Port-Harcourt, River State in the Niger Delta. Participants who are natives of River State are called native-born while those who are not natives of River state are called non-natives. Majority of the residents/ participants were young, unemployed, native-born with at least secondary/high school education. These demographic characteristics are presented below:

Sex: Male $=67 \%$; Female $=33 \%$

Age: Younger $=81 \%$; Older $=19 \%$

Nativity Native $=88 \%$; Non-natives $=12 \%$

Employment Status: Employed $=30 \%$; Unemployed $=70 \%$

Educational Level: No formal education $=9 \%$; Primary $/$

Secondary $=37 \%$; Tertiary $=54 \%$

\section{Hypotheses Testing}

Results of analysis carried out to test hypotheses previously stated were presented in form of tables.

Observation of means score revealed in Table 1 indicated that male participants exhibited higher environmental worry $(\bar{X}=3.16$; SD $=0.43)$ than female participants $(\bar{X}=2.96$; $\mathrm{SD}=0.46)$. The result in Table 1 demonstrated that there is a significant difference on environmental worry based on sex $(\mathrm{t}=$ 2.17; $\mathrm{df}=98 ; p<.05)$. This indicated that male participants manifested significant higher environmental worry than female participants.

Observation of means score revealed in Table 1 indicated that non-natives participants exhibited higher environmental 
Table 1.

Independent t-test showing comparison of mean difference of sex, nativity, age and employment status on environmental worry.

\begin{tabular}{|c|c|c|c|c|c|c|c|}
\hline Variables & Group & $\mathrm{N}$ & $\bar{X}$ & SD & $\mathrm{t}$ & df & $p$ \\
\hline \multirow[t]{2}{*}{ Sex } & Male & 67 & 3.16 & 0.43 & 2.17 & 98 & $<.05$ \\
\hline & Female & 33 & 2.96 & 0.46 & & & \\
\hline \multirow[t]{2}{*}{ Nativity } & Natives & 88 & 3.09 & 0.45 & 0.50 & 98 & $>.05$ \\
\hline & Non-natives & 12 & 3.12 & 0.38 & & & \\
\hline Age & Young & 81 & 3.07 & 0.43 & 2.30 & 98 & $<.05$ \\
\hline \multirow[t]{2}{*}{ Employment } & Employed & 30 & 3.10 & 0.48 & 0.14 & 98 & $>.05$ \\
\hline & Unemployed & 70 & 3.12 & 0.41 & & & \\
\hline
\end{tabular}

worry $(\bar{X}=3.12$; SD $=0.38)$ than native-born participants $(\bar{X}$ $=3.09$; $\mathrm{SD}=0.45)$. The result in Table 1 demonstrated that there was no significant difference on environmental worry based on nativity $(\mathrm{t}=.50 ; \mathrm{df}=98 ; p>.05)$. This showed that there is no difference between environmental worry of nativeborn and non-native participants.

Observation of means score revealed in Table 1 indicated that older participants $(\bar{X}=3.63$; SD $=.48$ ) exhibited higher environmental worry than younger participants $(\bar{x}=3.07$; SD $=.43)$. The result in Table 1 indicated that environmental worry was significantly different influenced by age $(\mathrm{t}=2.30$; $\mathrm{df}=98$; $p<.05)$. This indicated that older participants manifested sig nificant higher environmental worry than younger participants.

The result in Table 1 demonstrated that there was no significant difference on environmental worry based on employment status $(\mathrm{t}=.14 ; \mathrm{df}=98 ; p>.05)$. This showed that there is no difference between environmental worry of unemployed and employed participants.

The one way ANOVA result in Table 2 showed that there was no statistical significant difference regarding the participants' environmental worry based on educational status $\mathrm{F}(2,91)$ $=.30 ; p>.05$. This showed that there was no difference in environment worry exhibited by participants based on their educational status.

\section{Discussion}

\section{Discussion of Findings for Survey}

From the survey, the finding in this study that male participants exhibited higher environmental worry than female participants supported (Hokka et al., 1999; Sjoberg, 1998) studies. Stokols theory of behavioural constraint theory purported that when persons experience discomfort in their environment, they reassert control over the event termed psychological reactance (Sjoberg, 1998). Apparent as male participants in the SouthSouth resorted to aggressive reaction (Ehigie, 2005). The Niger Delta is part of the South-South geopolitical zone of Nigeria.

The findings of this study demonstrated that older people exhibited more environmental worry than younger people. This corroborated the study of (Drottz-Sjoberg \& Sjoberg, 1990). Some of the older people have lost the traditional job opportunities (Grattan et al., 2011) such as farming and fishing as reported by the FGD. The people worry because they lack essentials of life like employment (Eisenberger et al., 1998). They are getting older but according to the FGD, there are no cases of suicide, however, they are helpless. The older people therefore resorted to learned helplessness. Learned helplessness is
Table 2.

One way ANOVA showing differences in educational status on environmental worry.

\begin{tabular}{cccccc}
\hline & $\begin{array}{c}\text { Sum of } \\
\text { squares }\end{array}$ & $\begin{array}{c}\text { Mean of } \\
\text { squares }\end{array}$ & df & F & $p$ \\
\hline $\begin{array}{c}\text { Between } \\
\text { groups }\end{array}$ & 0.12 & 0.06 & 2 & 0.30 & $>.05$ \\
$\begin{array}{c}\text { Within } \\
\text { groups }\end{array}$ & 17.43 & 0.19 & 91 & & \\
Total & 17.54 & & 93 & & \\
\hline
\end{tabular}

the third level in behaviour constraint theory (Stokols, 1978) purporting that when one repeatedly experiences lack of control in altering bad events, humans develop the belief that they are helpless and simply give up trying to change the outcome (Seligman \& Maier, 1967). Learned helplessness although is less severe than death actually often leads to death (Seligman, 1992).

The finding of the present study that there was no significant difference between employed and unemployed residents in exhibiting environmental worry did not support (Grattan et al., 2011) that participants with oil spill-related income loss and loss of job opportunities were less resilient. The finding that environmental worry did not differ according to educational status did not corroborate the findings of (Grattan et al., 2011) that lower educational level is tied to higher worry. The non-significant results supported the FGD report that all residents are stakeholders, irrespective of their demographic group.

\section{Conclusion}

The FGD result revealed loss of land and loss of controllability in the technical network of oil exploration in Niger Delta; knowledge and experience of man-made environmental degradation, residents exhibition of worry about survival; identification of poor representation from the community leaders and neglect by companies and government.

The findings of the survey revealed that there was a significant difference of sex and age on environmental worry. However, nativity, employment status and educational status did not significantly differentiate between groups on environmental worry among residents of the Niger Delta.

\section{Limitation of Study}

This study made use of only exposed residents. Future studies should make use of both exposed and non-exposed residents of Niger Delta in order to make comparative analysis. The peo- 
ple in Niger Delta are very sensitive especially in oil producing and industrial areas. Women though invited did not come to the FGD; no explanation was given by the men. The researchers were not allowed to visit the chief because the youth may become inquisitive, agitated and protest. Access to the companies was denied as this was written on the sign posts at the gates.

\section{Implication and Recommendation}

There should be psychological intervention for leaders to impact the psychosocial domain of the residents. There should be public enlightenment programmes on avoidance of exposure to uncontrollable technological dangers, choices of edibles, living and enduring life style. Government should take a vital role in empowerment of youth through skill acquisition programmes. Alleviation of social problems through intervention in delivery of primary health care is to the grass root, education, employment, food, potable water and electricity. Companies to relate directly with the residents in the communities and not through their community leaders, give employment to the residents especially the native-born residents. Distributive justice based on equity, need and equality should be practiced. Equity is applied as deserved, need in prioritising development and equality among the people of the Niger Delta. Government should reach all the demographic groups in the Niger Delta.

\section{Acknowledgements}

The researchers are sincerely grateful to the Management of Redeemer's University who provided grant to embark on this study.

\section{REFERENCES}

Adams, J. S. (1965). Inequality in social exchange. In L. Berkowitz (Ed.), Advances in Experimental Social Psychology (pp. 267-299). New York: Academic Press.

Adeola, F. O. (2007). Nativity and environmental risk perception: An empirical study of native-born and foreign-Born residents of USA. Human Ecology Review, 14.

Akinbobola, O. I. (2012). Environmental worry as correlate of selfesteem among employed and unemployed people in oil industry environment. International Journal of Psychology and Behavioral Sciences, 2, 167-172.

Akinbobola, O. I., \& Njor, B. E. (2013). Environmental worry: Assessing risk perception and perceived marginalisation of residents of the Niger Delta. Nigeria Redeemer's University Journal of Management and Social Sciences, 1, 92-98.

Babalola, S. S. (2010). The impact of length of unemployment and perceived organizational support on employee's emotional needs. Ifepsychologia, 18, 119-136.

Bowler, R. M., \& Schwarzer, R. (1991). Environmental Anxiety: Assessing emotional distress and concerns after toxin exposure. Anxiety, Stress and Coping, 4, 167-180.

Brehm, S. S., \& Brehm, J. W. (1981). Psychological Reactance: A Theory of Freedom and Control. New York: Academic Press.

Bruce, V., \& Young, A. (1988). In the Eye of the Beholded: The Science of Face Perception. Oxford University Press.

Crayford, S. (1996). The Ogoni uprising: Oil, human rights and a democratic alternative in Nigeria. Africa Today, 43, 183-193.

Deutsch, M. (1975). Equity, equality, and need: What determines which value will be used as the basis of distributive justice? Journal of Social Issues, 31, 137-149.

Drottz-Sjoberg, B. M., \& Stoberg, L. (1990). Risk Perception and worries after the Chernobyl accident. Journal of Environmental Psychology, 10, 135-149.
Ehigie, B. O. (2005). Ethnic differences and perceived marginalisation as psychological issues of conflict in Nigeria. Nigerian Journal of International Affairs, 31, 71-89.

Ehigie, B. O., \& Ideozu, C. I. (1999). Psychological Consequences of Environmental degradation: A Case Study of the Niger Delta. Proceeding of the 18th Annual conference of the Nigerian Psychological Association, University of Lagos.

Eisenberger, R., Armeli, S., Fasolo, P., \& Lynch, P. (1998). Perceived organisational support and police performance: The moderating influence of socio-emotional needs. Journal of Applied Psychology, 83, 288-297.

Forsyth, D. R. (2006). Conflict. In D. R. Forsyth (Ed.), Group Dynamics (5th ed., pp. 388-389). Wadsworth: Cengage Learning Belmont.

Garber, J., \& Seligman, M. E. P. (1981). Human helplessness: Theory and applications. New York: Academic Press.

Grattan, L. M., Roberts, S., William, T., Mahan, W. T., Patrick, K., McLaughlin, P. K., Steven, W., Otwell, W. S., \& Morris, J. G. (2011). The Early Psychological Impacts of the Deepwater Horizon Oil Spill on Florida and Alabama Communities. Environment Health Perspective, 119, 838-843.

Herr, C. E. W., Rethage, T., Kopka, I., zur Nieden, I. A., Korner, I. E., Osadnik, I. R., Stilianakis, N., Hodapp, V., \& Eikmann T. F. (2000). Comparing environmental worry in 1996 and 2000 in environmental related studies. Epidemiology, 13, 251.

Hokka, P., Palosuob, H., Zhuralevac, I., Parnad, K., Mussalo-Rauhamaab, H., \& Lakomovac, N. (1999). Anxiety about environmental hazards among teenagers in Helsinki, Moscow and Tallinn. The Science of the Total Environment, 234, 95-107.

Krueger, R. A. (1998). Focus Groups. A Practical Guide for Applied Research (2nd ed.). CA: Sage Thousand Oaks.

Nwoke, M. B. (2011). Perception of the relationship between oil exploitation and environmental degradation in the Niger Delta, region: Psychological implications. African Journal for the Psychological Study of Social Issues, 14.

Obadan, M. I., \& Chokor, B. A. (2013). Yesterday, Today and Tomorrow Proceedings of the Niger Delta Stakeholders conference of the Ministry of Niger Delta Affairs on coordinating Development Initiatives for the Transformation of the Niger Delta.

Pegg, S., \& Zabbey, N. (2013). Oil and water: The Bodo spills and the destruction of traditional livelihood structures in the Niger Delta. Community Development Journal, 48, 391-405.

Rodin, J., \& Baum, A. (1978). Crowding helplessness: Potential consequences of density and loss of control. In A. Baum, \& Y. Epstein (Eds.), Human Response to Crowding. Hillsdale, NJ: Erlbaum.

Seligman, M. E. P. (1992). Helplessness: on depression, development and death (2nd ed.). New York: W. H. Freeman.

Seligman, M. E. P., \& Maier S. F. (1967). Failure to escape traumatic shock. Journal of Experimental Psychology, 74, 1-9.

Shusterman, D., Lipscomb J., Neutra R., \& Satin K. (1991). Symptom prevalence and odour-worry interaction near hazardous waste sites. Environmental Health Perspectives, 94, 25-30.

Sjoberg, L. (1998). Worry and risk perception. Risk Analysis, 18, 85-93.

Sjoberg, L., \& Drottz-Sjoberg, B. M. (1987). Psychological reactions to cancer risks after the Chernobyl accident. Medical Oncology Tumor Pharmacother, 4, 259-271.

Sjoberg, L., \& Drottz-Sjoberg, B. M. (1993). The Perceived risk of nuclear waste. Proceedings of the SRA-Europe. In P. Vestrucci, \& R. A. Cox (Eds.), Fourth Conference: European Technology and Experience in Safety Analysis and Risk Management, Rome.

Stokols, D. (1978). Environmental psychology. Annual Review of Psychology, 29, 253-295.

Udogu, E. I. (2005). Nigeria in the twenty first century: Strategies for political stability and peaceful coexistence. New York: Africa World Press.

United Nations Development Program-UNDP (2006). Niger Delta Human Development Report. Main Report and Summary.

Wohlwill, J. F. (1974). Human response to levels of environmental stimulation. Human Ecology, 2, 127-147.

World Bank (2007). Nigeria Country Brief. Washington: World Bank. 